Plant Tissue Cult. \& Biotech. 31(1): 61-69, 2021 (June)

(C)Bangladesh Assoc. for Plant Tissue Culture \& Biotechnology

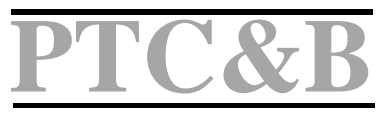

\title{
In vitro Micropropagation of Pomegranate (Punica granatum L.) Derived from Cotyledon
}

\author{
M.H. Kabir, Pronabananda Das*, A.N.K. Mamun, Md. Monirul Islam \\ and Md. Aminul Islam
}

Plant Biotechnology and Genetic Engineering Division, Institute of Food and Radiation Biology, Bangladesh Atomic Energy Commission, Ganakbari, Savar, G.P.O. Box No. 3787, Dhaka-1000, Bangladesh.

Key words: In vitro regeneration, Cotyledon culture, Pomegranate, Acclimatization, Plant growth regulators.

\begin{abstract}
A high frequency in vitro plant regeneration of pomegranate was established on MS medium supplemented with different concentrations and combinations of plant growth regulators. As explant cotyledons were employed for this study. Ninety percent of the cultured explants responded to form shoots from 30 days old in vitro raised seedlings after 90 days of culture initiation in MS containing $1.0 \mathrm{mg} / \mathrm{IBA}+0.1 \mathrm{mg} / \mathrm{NAA}$. The average number of shoots per explant was $10.0 \pm 2.20$, shoot length of $12.0 \pm 2.40 \mathrm{~cm}$, node per regenerated shoot was $9.0 \pm 1.60$ and the leaf number was $14.0 \pm 1.40$. Well developed shoots were cultured on half strength of MS medium supplemented with 0.5 mg A IBA, in which 90\% shoot induced roots implanted after one month. The average number of root per shoot was $8.0 \pm 0.90$ and the average root length of $6.5 \pm 0.40 \mathrm{~cm}$ was observed in this medium. Eighty percent plantlets were survived in the outdoor condition during the acclimatization period of seven days.
\end{abstract}

\section{Introduction}

Pomegranate is a fruit-bearing deciduous small tree and belongs to the family of punicaceae (Popenoe 1974). It is an economically important plant which is growing tropical and sub-tropical regions of the world due to its delicious edible traits with pharmaceutical and ornamental usage (Jayesh and Kumar 2004). The fruit is largely used as a dessert and the seeds along with the fleshy pulp called aril are dried and also used as a condiment (Raj and Kamlesh 2010). The fruit juice is a good source of sugars, vitamin C, vitamin B, pantothenic acid, potassium, antioxidant polyphenols, fibre and a fair

*Author for Correspondence: <daspronab12@gmail.com>

DOI: https://doi.org/10.3329/ptcb.v31i1.54112 
source of iron (Raj and Kamlesh 2010, Fuhrman and Aviram 2007). It is considered native to Iran, Afganistan, Pakistan and India. In the time it is diffused and has been cultivated widely in China, North Africa and Mediterranean Europe (Decandolle 1967, Zukovskij 1950, Raj and Kamlesh 2010). In Bangladesh, it is commonly known as Anar or Bedana and cultivated only at homestead area. But growing demand is increasing due to its delicious properties and haemoglobin improvement elements and also preferred as a delightful food for the patient. It is conventionally propagated by air layering or hardwood and softwood cuttings (Samir et al. 2009, Jalikop 2010, Pal and Singh 2017). But the establishment of new plants requires one year and carrying insect-pest-diseases and also limited due to lack of mother plants. Thus, the present investigation would help in overcoming the difficulties of vegetative propagation and rapid mass production of disease-free propagules. Moreover, this technique is used for long term storage of the clones and also useful for crop improvement via genetic transformation. A number of reports are available on micropropagation of pomegranate over the past few years (Sara et al. 2020, Bachake et al. 2019). Protocols have been developed from the regeneration of callus through leaf segments (Omura et al. 1987, Murkute et al. 2002), through cotyledon explants (Murkute et al. 2002, Raj and Kamlesh 2008, Kanwar et al. 2010) and anther culture (Moriguchi et al. 1987). Plant regeneration through embryogenesis has been reported from various seedling explants (Jaidka and Mehra 1986), from petal explants (Nataraja and Neelambika 1996) and from immature zygotic embryos (Bhansali 1990, Kanwar et al. 2010). In vitro propagation of pomegranate through axillary shoot proliferation using nodal segments (Zhang and Stolz 1991, Naik et al. 1999, 2000, Murkute et al. 2004, Kanwar et al. 2004), shoot tips (Murkute et al. 2004) and cotyledonary nodes (Sharon and Sinha 2000) has also been reported. Micropropagation in pomegranate can be initiated through the regeneration of existing meristems and/or regeneration from adventitious meristems or through regeneration by somatic embryogenesis (Guruanna et al. 2017). So far, in our knowledge, there has been hardly a single report done in the country regarding in vitro propagation of exotic pomegranate using cotyledon as explants. Thus, the present study was conducted to establish a reproducible protocol for large scale in vitro production of propagules of a pomegranate without any seasonal barrier using different concentrations and combinations of plant growth regulators and cotyledon as explants.

\section{Materials and Methods}

Fully ripen fruit of pomegranate (Punica granatum L.) was collected from the local market. The juicy pulp was removed from the seeds and subsequently washed thoroughly for 20 minutes under running tap water. The seeds were surface sterilized by treating with an aqueous solution of $0.1 \%$ mercuric chloride accompanied with 2 drops of 'tween 20' for 10 minutes in the laminar airflow cabinet under aseptic conditions. Rinsing 
was done 4 times with sterile distilled water. Sterilized seeds were then cultured on MS + $0.2 \mathrm{mg} / \mathrm{BA}+0.2 \mathrm{mg} / \mathrm{GA} 3$ for raising in vitro seedlings.

Cotyledons of 30 days old in vitro raised seedlings were excised aseptically and cultured on to MS medium supplemented with different concentrations of BA and Kn either single or in combinations with NAA for multiple shoot formation. Sub-culture was done after 30 days interval on the same medium for promoting strong and healthy multiple shoots. Morphologically healthy shoots were excised individually and transferred to half strength of MS basal medium supplemented with different concentrations of IBA, IAA and NAA for root induction. The sucrose (table sugar) concentration was used $30 \mathrm{~g} A$ and the $\mathrm{pH}$ of the media adjusted to 5.8 prior to autoclaving. Cultures were incubated at $26 \pm 2{ }^{\circ} \mathrm{C}$ with a 16 hour illumination of 21.8 $\mu \mathrm{mol} / \mathrm{cm}^{2} / \mathrm{s}$ provided by cool white fluorescent tubes. In vitro raised plantlets were removed from culture vessels, washed thoroughly to remove traces of nutrient medium, transferred to poly bags and placed outdoor condition for acclimatization.

Data were collected on different characters at day 90 for multiple shooting and at day 30 for rooting of shoots. Observations on culture were carried out daily. The experiments were arranged in a completely randomized design (CRD) with three replications for each treatment and five explants per replication. Each experiment was repeated twice. A descriptive analysis was carried out using the recorded data. Each value represents Mean \pm standard errors.

\section{Results and Discussion}

Shoot initiation from the cotyledon explants (Fig. 1a) was observed in most of the media used except the media containing $0.5 \mathrm{mg} / \mathrm{BA}$ and $0.5 \mathrm{mg} / \mathrm{Kn}$ alone used in the study. It was found that shoot proliferation differed according to media component used (Table 1). Among the media component used, the combination of $1.0 \mathrm{mg} / \mathrm{BA}+0.1 \mathrm{mg} / \mathrm{NAA}$ was found to be the best for shoot proliferation, in which $90 \%$ explants produced shoots (Fig. $1 \mathrm{~b}$ ). The average number of shoot per explant was $10.0 \pm 2.20$, average shoot length of $12.0 \pm 2.40 \mathrm{~cm}$, average number of node per regenerated shoot was $9.0 \pm 1.60$ and the average leaf number of $14.0 \pm 1.40$ were observed in this medium culture after 90 days. A good response towards shoot formation and shoot multiplication of pomegranate by using BA + NAA was reported (Bandok et al. 1986, Murkute et al. 2004, Rudra and Juwarkar 2002, Singh 2003). These are in agreement with the present investigation. All concentrations of $\mathrm{BA}$ and $\mathrm{Kn}$ alone and in combination of $\mathrm{Kn}+$ NAA showed the decreasing trend of explants proliferation in terms of average number of shoots, shoot length, node counting and leaf number compared to that of combination BA + NAA. This indicates that the combination of $\mathrm{BA}+\mathrm{NAA}$ is the best for shoot proliferation and multiplication in vitro and $1.0 \mathrm{mg} / \mathrm{BA}+0.1 \mathrm{mg} / \mathrm{NAA}$ was found most optimum for in vitro regeneration of pomegranate. The occurrence of better response towards shoot formation and multiplication using BA + NAA was reported by many authors with other 
plants (Roy et al. 2011 in sugarcane var. Isd 16, Roy and Kabir 2007a in sugarcane var. Isd 32, Roy and Kabir 2006 in sweet orange, Roy and Kabir 2007b in apple, Rahman et al. 1999 in Emblica officinalis, Munshi et al. 2007 in cabbage, Kabir et al. 2006 in orchid cv. Sonia). Rooting response differed according to concentration of different auxins used (Table 2). Among the auxins used, IBA was found most responsive and $0.5 \mathrm{mg} \Lambda$ IBA was showed optimum, in which $90 \%$ shoots with roots (Fig. 1c) after 30 days of culture initiation in this medium. The average number of roots per shoot was $8.0 \pm 0.90$ and the average root length was $6.50 \pm 0.40 \mathrm{~cm}$. In vitro raised shoots responded well for root induction at low concentrations of IBA and did not response at all when the concentrations were increased

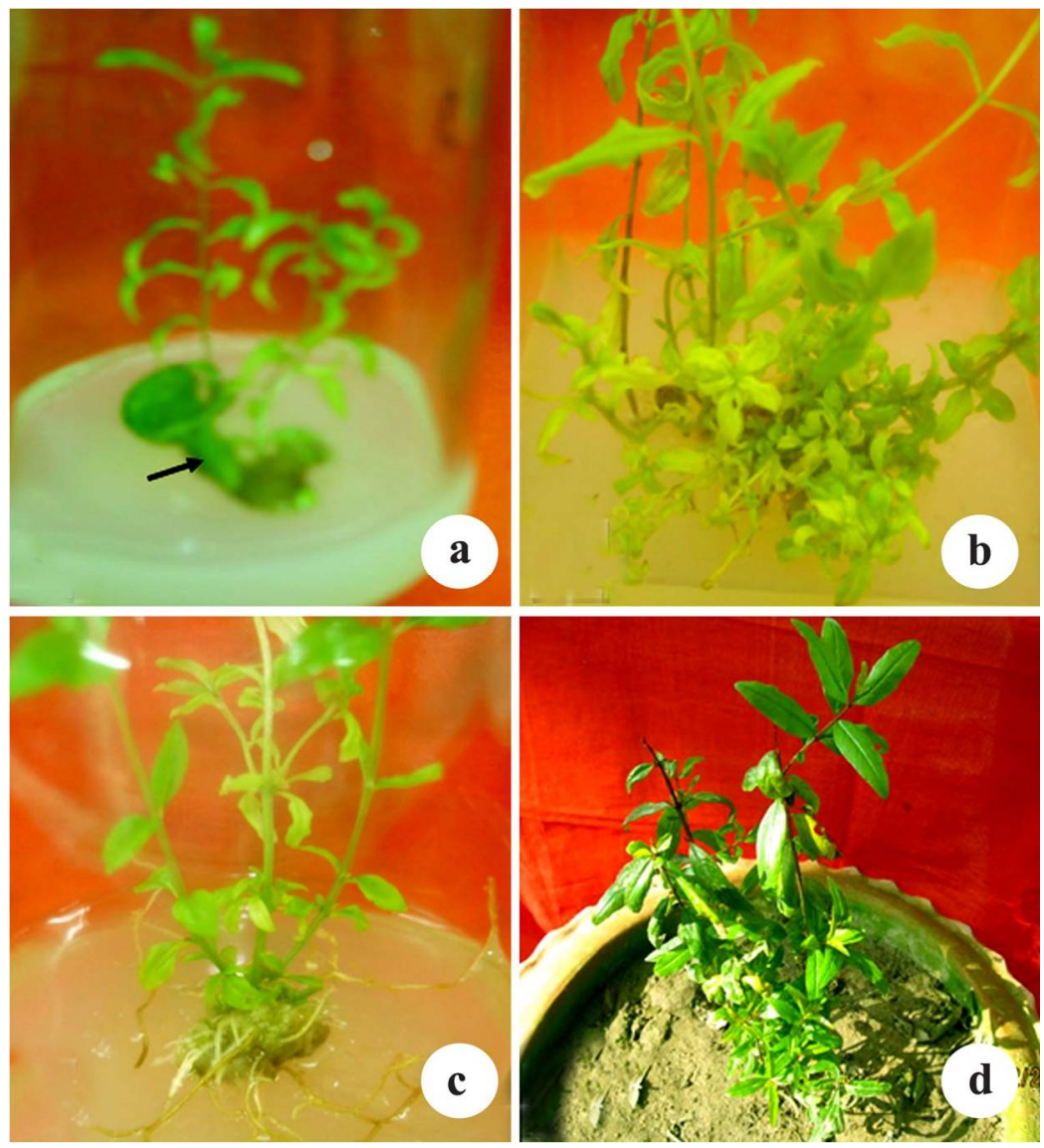

Figs 1. In vitro plant regeneration of pomegranate (Punica granatum L.) through cotyledon culture. a). Shoot initiation on MS $+1.0 \mathrm{mg} / \mathrm{BA}+0.1 \mathrm{mg} / \mathrm{NAA}$ (arrow pointed cotyledon). b). Multiple shoot formation in the same medium at sub-culture 4 whilst sub-culture followed 1 month interval. c). Root induction on half strength MS $+0.5 \mathrm{mg} /$ IBA. d). In vitro raised plants resumed new growth in earthen pot. 
up to $1.25 \mathrm{mg} A$ and higher than that. This indicates that a high concentration of IBA is toxic for root induction of pomegranate. Similar observations were reported by Samir et al. (2009) in Nab E1-gamal cultivar and Murkute et al. (2004) in Ganesh cultivar of pomegranate. On the contrary, NAA induced rooting has already been reported in Punica granatum L. by several authors (Omura et al. 1987, Mahishui et al. 1991, Yang and Ludders 1993, Amin et al. 1999, Naik et al. 2000, Naik and Chand 2003, Zhu et al. 2003).

Table 1. Effect of different concentrations and combinations of plant growth regulators in MS on shoot proliferation from cotyledon explants in exotic pomegranate at 90 days.

\begin{tabular}{|c|c|c|c|c|c|}
\hline $\begin{array}{l}\text { Plant growth } \\
\text { regulators } \\
(\mathrm{mg} /)\end{array}$ & $\begin{array}{l}\% \text { of explants } \\
\text { forming } \\
\text { shoots }\end{array}$ & $\begin{array}{c}\text { Av. no. of } \\
\text { shoots/explants } \\
\text { Mean } \pm \text { SE }\end{array}$ & $\begin{array}{l}\text { Av. shoot length/ } \\
\text { explants }(\mathrm{cm}) \\
\text { Mean } \pm \text { SE }\end{array}$ & $\begin{array}{c}\text { Av. no. of } \\
\text { nodes/explants } \\
\text { Mean } \pm \text { SE }\end{array}$ & $\begin{array}{c}\text { Av. no. of } \\
\text { leaf/explants } \\
\text { Mean } \pm \text { SE }\end{array}$ \\
\hline \multicolumn{6}{|l|}{ BA } \\
\hline 0.5 & - & - & - & - & - \\
\hline 1.0 & 50 & $5 \pm 0.60$ & $6 \pm 0.50$ & $6 \pm 0.60$ & $10 \pm 0.90$ \\
\hline 1.5 & 50 & $5 \pm 0.80$ & $4.5 \pm 0.60$ & $5 \pm 0.30$ & $8 \pm 0.60$ \\
\hline 2.0 & 20 & $3 \pm 0.20$ & $4 \pm 0.40$ & $4 \pm 0.30$ & $6 \pm 0.40$ \\
\hline \multicolumn{6}{|l|}{ Kin } \\
\hline 0.5 & - & - & - & - & - \\
\hline 1.0 & 60 & $3 \pm 0.40$ & $4 \pm 0.20$ & $4 \pm 0.60$ & $6 \pm 0.40$ \\
\hline 1.5 & 40 & $2 \pm 0.30$ & $4 \pm 0.40$ & $4 \pm 0.30$ & $6 \pm 0.20$ \\
\hline 2.0 & 30 & $2 \pm 0.30$ & $3 \pm 0.30$ & $3 \pm 0.20$ & $4 \pm 0.20$ \\
\hline \multicolumn{6}{|l|}{$\mathrm{BA}+\mathrm{NAA}$} \\
\hline $0.5+0.1$ & 60 & $4 \pm 0.60$ & $5 \pm 0.70$ & $4 \pm 0.60$ & $6 \pm 0.30$ \\
\hline $1.0+0.1$ & 90 & $10 \pm 2.20$ & $12 \pm 2.40$ & $9 \pm 1.60$ & $14 \pm 1.40$ \\
\hline $1.5+0.1$ & 40 & $6 \pm 0.90$ & $6 \pm 0.40$ & $5 \pm 0.70$ & $8 \pm 0.60$ \\
\hline $2.0+0.1$ & 40 & $3 \pm 0.40$ & $4 \pm 0.30$ & $4 \pm 0.40$ & $6 \pm 0.40$ \\
\hline \multicolumn{6}{|l|}{$\mathrm{Kn}+\mathrm{NAA}$} \\
\hline $0.5+0.1$ & 40 & $2 \pm 0.20$ & $4 \pm 0.30$ & $4 \pm 0.30$ & $4 \pm 0.30$ \\
\hline $1.0+0.1$ & 50 & $5 \pm 0.70$ & $6 \pm 0.50$ & $6 \pm 0.40$ & $8 \pm 0.70$ \\
\hline $1.5+0.1$ & 40 & $3 \pm 0.40$ & $4 \pm 0.40$ & $4 \pm 0.50$ & $6 \pm 0.40$ \\
\hline $2.0+0.1$ & 20 & $2 \pm 0.30$ & $4 \pm 0.20$ & $4 \pm 0.60$ & $6 \pm 0.30$ \\
\hline
\end{tabular}

- = No response

But, in the present study, it was found that rooting responded from NAA and IAA supplemented media is extremely poor. This might be due to the effect of genotype. The superiority of IBA for rooting over other auxins has also been reported (Jaiswal and Amin 1987, Amin and Akhter 1983, Amin et al. 1992, Grewal et al. 1994). Comparatively 
healthy rooted shoots were taken out from the culture vessels and washed gently under running tap water to get rid of agar. The in vitro rooted plantlets were then transferred to earthen pots (Fig. $1 \mathrm{~d}$ ) containing a mixture of soil and compost (2:1) and covered with transparent polyethylene lid to maintain high humidity. After one week, the polyethylene lids were removed and plantlets were kept in a shade and misted twice a

Table 2. Effect of IBA, IAA and NAA on half strength MS media in root induction of in vitro raised shoot of exotic pomegranate at 30 days.

\begin{tabular}{|c|c|c|c|c|}
\hline $\begin{array}{l}\text { Plant growth } \\
\text { regulators }\end{array}$ & $\begin{array}{c}\text { Concentrations } \\
\qquad(\mathrm{mg} /)\end{array}$ & $\begin{array}{l}\text { \% of shoots } \\
\text { inducing } \\
\text { roots }\end{array}$ & $\begin{array}{l}\text { Average number } \\
\text { of roots induced/ } \\
\text { shoot (Mean } \pm \text { SE) }\end{array}$ & $\begin{array}{l}\text { Average root length } \\
(\mathrm{cm})(\text { Mean } \pm \mathrm{SE})\end{array}$ \\
\hline \multirow[t]{7}{*}{ IBA } & 0.25 & 50 & $4 \pm 0.30$ & $5 \pm 0.30$ \\
\hline & 0.50 & 90 & $8 \pm 0.90$ & $6.50 \pm 0.40$ \\
\hline & 0.75 & 40 & $4 \pm 0.60$ & $4.5 \pm 0.30$ \\
\hline & 1.00 & 30 & $2 \pm 0.20$ & $4.0 \pm 0.60$ \\
\hline & 1.25 & 10 & $2 \pm 0.20$ & $3 \pm 0.20$ \\
\hline & 1.50 & - & - & - \\
\hline & 2.00 & - & - & - \\
\hline \multirow[t]{7}{*}{ IAA } & 0.25 & - & - & - \\
\hline & 0.50 & - & - & - \\
\hline & 0.75 & 10 & $2 \pm 0.30$ & $3 \pm 0.40$ \\
\hline & 1.0 & 20 & $2 \pm 0.10$ & $3 \pm 0.20$ \\
\hline & 1.25 & - & - & - \\
\hline & 1.50 & - & - & - \\
\hline & 2.00 & - & - & - \\
\hline \multirow[t]{7}{*}{ NAA } & 0.25 & - & - & - \\
\hline & 0.50 & - & - & - \\
\hline & 0.75 & - & - & - \\
\hline & 1.00 & 20 & $3 \pm 0.40$ & $3.5 \pm 0.40$ \\
\hline & 1.25 & - & - & - \\
\hline & 1.50 & - & - & - \\
\hline & 2.00 & - & - & - \\
\hline
\end{tabular}

- = Absent/No response

day. About $80 \%$ of the plantlets were resumed new growth within 30 days. A total number of 40 plantlets were survived in the field out of 50 in vitro regenerants. The development of efficient tissue culture protocol is necessary for conservation and genetic improvement of this valuable fruit crop. Hence, the protocol described in this study is repeatable and also long-term in vitro regeneration using cotyledon as explants. 


\section{Conclusion}

In vitro micropropagation ensures true to type and rapid multiplication of disease free propagules and such can be used as super elite variety(s) or genotype(s) for quick spread. Our study focused on using a particular concentration and combination of plant growth regulators which can play an important ingredient for better multiple shoot initiation and rooting ability to form into complete plantlets of pomegranate genotype. Moreover, the findings would be useful for development of direct organogenesis protocol in this species of other genotypes and genetic improvement through somaclonal variation and also genetic transformation and in vitro mutagenesis of this crop.

\section{Acknowledgement}

This study was supported by the Institute of Food and Radiation Biology, BAEC. The authors are thankful to the related personnel with this work.

\section{References}

Amin MN and Akhter S (1993) Regeneration of plants in vitro from seedling explants of pummelo (Citrus grandis). Plant Tissue Cult. 3: 71-79.

Amin MN, Razzaque MA and Akhter S (1992) Axillary shoot proliferation and adventitious rooting in vitro of carambola (Averrhoa carambola L.). Plant Tissue Cult. 2: 7-13.

Amin MN, Islam MN and Azad MAK (1999) Regeneration of plantlets in vitro from the seedling explants of pomegranate (Punica granatum). Plant Tiss. Cult. 9(1): 53-61.

Bachake SS, Jadhav VB, Deshpande PP, Tele AA, Banda MA, Adki VS, Gopika MK, Karanjule PG, Birajdar SB, Karwa NN, Mundhewadikar DM and Singh NV (2019) Standardization of in vitro propagation protocol for pomegranate cv. Super Bhagwa. Journal of Pharmacognosy and Phytochemistry. 8(3): 2548-2553

Bhansali RR (1990) Somatic embryogenesis and regeneration of plantlets in pomegranate. Anals of Botany. 66(3): 249-253.

Bondok AZ, Agamy SZEL, Gaber MF, Din LSEL and Khalil FA (1986) In vitro micropropagation of 'Wardi Red' pomegranate (Punica granatum L.). Egypt. J. Hort. 13(2): 103-108.

Decandolle A (1967) Origin of cultivated plants. Hafner publishers Co. New York. pp. 468.

Fuhrman B and Aviram M (2007) Pomegranate and cardiovascular diseases. Pomegranate juice polyphenolic antioxidants protect against oxidative stress and atherosclerosis development. Acta Horticulture. 744: 205-216.

Grewal HS, Dhatt AS and Gosal SS (1994) Plantlet regeneration from callus in citrus. Plant Tissue Cult. 4(1): 9-16.

Guranna P, Hosmani I, Sathyanarayana R, Hegde R, Hipparagi K (2017) Micropropagation in pomegranate (Punica granatum L.) $\mathrm{cv}$. Bhagwa through indirect organogenesis and assessment of genetic fidelity by RAPD marker. Biotechnology Journal International. 20: 1-8.

Jayesh KC and Kumar R (2004) Crossability in pomegranate (Punica granatum L.) Indian J. Hort. 61(3): 209-210. 
Jalikop SH, Venugopalan R and Kumar R (2010) Association of fruit traits and aril browning in pomegranate (Punica granatum L.). Euphytica. 174: 137-141.

Jaidka K and Mehra PN (1986) Morphogenesis in Punica granatum (Pomegranate). Canadian J. Botany. 64: 1644-1653.

Jaiswal VS and Amin MN (1987) In vitro propagation of guava from shoot culture of mature trees. J. Plant Physiol. 130: 7-12.

Kabir MH, Roy PK and Ahmed G (2006) In vitro propagation of Thuja occidentalis through apical shoot culture. Plant Tissue Cult. \& Biotech. 16(1): 5-9.

Kanwar K, Rana R and Kashyap A (2004) In vitro propagation of wild pome-granate (Punica granatum L.). In Jindal KK, Bawa R (Eds) Intellectual Pro-perty Rights, Shiva Offset Press, Dehradun,India,pp:209-215

Kanwar K, Joseph J and Deepika R (2010) Comparison of in vitro regeneration pathways in Punica granatum L. Plant cell Tiss. Organ cult. 100: 199-207.

Mahishni DM, Muralikishna A, Shivashankar G and Kulkarni RS (1991) Shoot tip culture method for rapid clonal propagation of pomegranate (Punica granatum L.) In: Horticulture new technologies and applications. Proc. Int. Seminar on new frontiers in Horticulture. IndoAmerican hybrid seeds. Bangalore. pp. 215-217.

Moriguchi T, Omura M, Matsuta N and Kozaki I (1987) In vitro adventitious shoot formation from anthers of pomegranate. Hort. Sci. 22: 947-948.

Munshi MK, Roy PK, Kabir MH and Ahmed G (2007) In vitro regeneration of cabbage (Brassica oleracea var. capitata) through hypocotyl and cotyledon culture. Plant Tissue Cult. \& Biotech. 17(2): 131-136.

Murkute AA, Patil S, Patil BN and Kumari M (2002) Micropropagation in pomegranate, callus induction and differentiation. South Indian Hort. 50: 49-55.

Murkute AA, Patil S, and Singh SK (2004) In vitro regeneration in pomegranate cv. Ganesh from mature trees. Indian J. of Hort. 61(3): 206-208

Naik SK, Patnaik S and Chand V (1999) In vitro propagation of pomegranate (Punica granatum L. $\mathrm{cv}$. Ganesh) through axillary shoot proliferation from nodal segments of mature tree. Sci. Hort. 79: 175-183.

Naik SK, Patnaik S and Chand PK (2000) High frequency axillary shoot proliferation and plant regeneration from cotyledonary nodes of pomegranate (Punica granatum L.). Sci. Hort. 85: 261 $-270$.

Naik SK, Patnaik S and Chand PK (2003) Silvernitrate and aminoethoxyvinyl glycine pomegranate in vitro adventitious shoot regeneration of pomegranate (Punica granatum L.). J. Plant Physiol. 160(4): 423 -430.

Nataraja K, Neelambika GK (1996) Somatic embryogenesis and plantlet from petal cultures of pomegranate, Punica granatum L. Indian J Exp Biol. 34(7): 719-21.

Omura M, Matsuta N, Moriguchi T and Kazaki I (1987) Adventitious shoot and plantlet formation from cultured pomegranate leaf explants. Hort. Sci. 22: 133-134.

Pal RK and Singh NV (2017) Pomegranate for nutrition, livelihood security and entrepreneurship development. Daya Publishing House (A division of Astral International Pvt. Ltd), New Delhi, India ${ }_{-}$

Popenoe W (1974) Manual of tropical and subtropical fruits. The MacMillan Company. pp. 375-383. 
In vitro Micropropagation of Pomegranate

Rahmah MM, Roy PK, Mannan MA and Roy SK (1999) Clonal Propagation of Emblica officinalis through in vitro culture. Pant. Tissue Cult. 9: 17-23.

Raj D and Kamlesh K (2008) Efficient in vitro shoot multiplication and root induction enhanced by rejuvenation of microshoots in Punica granatum cv. Kandhari kabuli. National seminar on physiological and biotechnological approaches to improve plant productivity. March 15-18. CCSHAU, Hisar, India. p. 24.

Raj D and Kamlesh K (2010) In vitro regeneration of Punica granatum L. Plants from different juvenile explants. Journal of Fruit and Ornamental Plant Research. 18(1): 5-22.

Roy PK, Mamun ANK, Kabir MH, Islam MR, Jahan MT and Rahman MZ (2011) In vitro indirect regeneration of sugarcane (Saccharum officinarum L.) var. Isd 16 through apical leaf culture. Bangladesh J. Life Sci. 23(1): 123-128.

Roy PK and Kabir MH (2006) In vitro propagation of sweet orange (Citrus sinensis) through plumule and cotyledon culture. Bangladesh J. Life Sci. 18(2): 107-112.

Roy PK and Kabir MH (2007a) In vitro mass propagation of sugarcane (Saccharum officinarum L.) var. Isd 32 through shoot tips and folded leaves culture. Biotechnology 6(4): 588-592.

Roy PK and Kabir MH (2007b) Micropropagation of Apple, Malus domestica Borkh through in vitro culture. Bangladesh J. Life Sci. 19(1): 107-113.

Rudra J and Juwarkar AS (2002) In vitro multiplication of Punica granatum Linn. cv. GBG-1 (Ganesh) through axillary bud cultures. Ad. Plant. Sci. 15(1): 5-10.

Samir Z, Agamy EL, Rafat A, Mostafa A, Mokhtar M, Shiaban and Mahdy MTEL (2009) In vitro propagation of manfalouty and Nab EL-gamal pomegranate cultivars. Research Journal of Agriculture and Biological Sciences. 5(6): 1169-1175.

Sara Mulaei, Azam Jafari, Mostafa Shirmardi and Kazem Kamali (2020) Micropropagation of Arid Zone Fruit Tree, Pomegranate, cvs. 'Malase Yazdi' and 'Shirine Shahvar'. International Journal of Fruit Science, 20(4): 825-836, DOI: 10.1080/15538362.2019.1680334

Sharon M and Sinha S (2000) Plant regeneration from cotyledonary node of Punica granatum L. Indian J. Plant Physiol. 5(4): 344-348.

Singh BK (2003) Studies on in vitro propagation of pomegranate (Punica granatum L.). Ph.D. Dissertation. CCS Haryana Agricultural University, Hisar, India. p. 85.

Yang ZH and Ludders P (1993) Organogenesis of Punica granatum L. var. Nana. Angewandte Botanik. 67(5-6): 151-156.

Zukovskij PM (1950) Punica. In: Cultivated plants and their wild relatives. State Publishing House. Soviet Science, Moscow. pp. 60-61.

Zhang BL and Stolz LP (1991) In vitro shoot formation and elongation of dwarf pomegranate. Hort. Sci. 26(8): 1084.

Zhu LW, Zhang SM, Song FS, Gong XM, Fang WJ, Sun J and Li SW (2003) Regeneration system of pomegranate by in vitro culture. Acta Hort. Sinica. 430(2): 207-208.

(Manuscript received on 23/02/2021; revised on 10/05/2021) 